\title{
THE ANALYSIS OF DIFFERENCES IN RESIDENTIAL PROPERTY PRICE INDICES
}

\author{
Sebastian Kokot \\ Department of Econometrics and Statistics \\ University of Szczecin \\ e-mail: sebastiankokot@o2.pl
}

\begin{abstract}
Residential property price indices can serve as a useful tool in the practice of real property market analysts, investment advisers, property developers, certified property appraisers, estate agents and managers. They can also be applied in property price valorization in specific legal positions. The Polish Act on Real Estate Management puts an obligation on the President of the Central Statistical Office to announce real property price indices, but the CSO fails to fulfill this obligation. The author's rationale for this article is to contribute to works on rules of how to build property price indices. Presented within are the results of research on determining the price indices of such types of residential property as: a part of a building constituting a separate property and strata titles in housing cooperatives. The flats were divided into categories by floor area and by their location in 16 voivodeship capitals. The major purpose of the study is to prove that the prices of flats of different floor area change at different rates. Consequently, it seems worth considering whether a more detailed segmentation of the real estate market would be worthwhile for the sake of more accurate real property price indicators.
\end{abstract}

Key words: real estate market, property price indices.

JEL Classification: R20.

Citation: Kokot S., 2014, The analysis of differences in residential property price indices, Real Estate Management and Valuation, vol. 22, no. 3, s. 14-27.

DOI: 10.2478/remav-2014-0023

\section{Background}

In Poland, studies regarding price dynamics on the real estate market are not conducted in a systemic manner, although the results of such a survey should constitute an essential part of the property appraisers' workshop because, according to the Polish law, property price adjustment due to the passing of time is an obligatory element of the appraisal procedure (2004 Regulation). The accurate estimation of price indices for residential property is an essential feature of real estate research (CLAPP, GIACOTTO 1992). Many organizations and individuals, such as financial institutions or house owners, are interested in house price movements (FRANCKE 2010). What is more, the skill of observing fluctuations of property prices is useful in other real estate market jobs, such as real estate analysts, investment advisers, developers or estate agents and managers, for whom real property price indices are an extremely useful tool.

Due to a specific nature of the real estate market, the methods applied in determining price indices of other valuable goods can only be used on this market to a limited extent (WOOD 2005). In practice, real property price indices reflect reality with varying precision (TROJANEK 2008, 2009, 2010). In the world of transaction price indices used to track dynamics in housing markets, the problem of controlling for heterogeneity in the housing transactions in different periods of time is perhaps the most crucial (GUO et al. 2014). 
On the real estate market, the observations of transaction prices expressed as statistical variables are performed in a non-standard way. In the classical approach, every period of or moment in time is attributed with one observation of a variable of interest per one object (e.g. the population at the end of a year, the volume of debt at the end of each quarter, etc.). If we were to observe the real estate market in an analogical manner, we would have to do it regularly, for instance by observing the transaction price of a specific property on a monthly basis, which is obviously not possible (KOKOT, BAS 2013). The fundamental problem is the scarcity of transaction data for index estimation (BOKHARI, GELTNER 2010). Transactions on the real estate market pertain to different objects - real property - and occur at irregular, or random, moments (FORYŚ, KOKOT 2001). As a result, a necessity arises to adapt traditional methods of observing the dynamics of economic phenomena to the specific conditions of the real estate market.

Market transaction prices are the most reliable source of information for valuation, with three commonly used methods of constructing price indexes. The first simply computes an average or a median price of all transactions, without any attempt to control for the heterogeneity of sold houses. A more advanced index of this sort is computed for a specific housing type, such as, for example a semidetached house of a certain size and quality. But the finer the partition, the greater the data requirements. An advantage is the ease of computing. A major drawback is that the selection of houses up for sale may vary endogenously. The second commonly used index is the repeat sales index. It is estimated based on price changes of the same house between subsequent transactions that are then weighted across houses. The index may produce biased estimates if the selection of houses that transact frequently is atypical; for example, if such houses tend to be of a higher quality than the general housing stock. The third index is the hedonic price index. It views a house as a collection of priced services and sums up these prices to obtain the value of the house. This methodology has many advantages. One potential drawback is the need to collect information on the multitude of housing attributes that influence the value of the house, and such data may be unavailable (NICHOLAS, SCHERBINA 2013).

Disregarding which method of building real property price indices we use and what associated technical problems (generally coming down to data availability and quality) we encounter, all of the methods are burdened with a difficult to assess faultiness of results, as we are never confident if the constructed and calculated indices reflect the real price changes accurately enough. The researcher can and should minimize these errors using certain tricks of the trade, but will never be able to achieve absolute certainty as to the outcome. One of such tricks is to increase the number of input data (i.e. prices) on the basis of which the indices are going to be calculated. As researchers are not able to control the number of transactions on the market, they can "expand" the observation periods. Unfortunately, this brings a negative effect in the form of quarterly or semi-annual indices instead of monthly ones. Another way of increasing the number of input data is to base indices on offer prices, as data on these prices always outnumbers that of transaction ones. The concept of using offer prices as well as fragmentary analyses of the real estate market appeared in Poland as early as in the 1990s (KośKA 1996, GŁOWACKI, PRZEWŁOCKI 1997, KOKOT 2000, TROJANEK 2008). As a rule, the levels of real property offer prices differ from transaction prices. However, if we are not interested in property prices as such but in their relative changes, offer prices prove to be a good source of information, especially if indices determined on their basis are used for the comparison of such prices in the local market sub-segments, i.e. when the compared measures are burdened with an analogical error.

It is difficult to demonstrate explicitly how accurately offer price indices reflect the real property price indices. Some studies on this matter gave rather promising answers. For instance, in 1996-2005 in Poznan, the correlation coefficient between the mean quarterly offer and transaction prices amounted to 0.99 (TROJANEK 2008). In several other Polish cities the correlation coefficient in 2006-2012 was higher than 0.9 (though in other cities it was below this value) (DITTMANN 2013). No matter how we look at it, it appears that this question requires further investigation.

The elementary advantage of information on offer prices is its abundance. Its shortcomings resulting from the fact that some offers are dubious can be reduced by means of measures of location (medians, dominants) used in order to determine mean prices in individual periods of time. It is also important to note that for the past few years, the market of internet services has been offering specialized websites where real estate agents can advertise properties on sale. It is a good thing that each offer appears on the page for a limited period of time, as this prevents the results of analyses 
based on such data from being distorted due to outdated information, which often happens when real estate agents run their own websites. What is more, such specialized internet services allow one to filter the listings according to criteria that correspond to some qualifying attributes which identify the analyzed market segment or sub-segment, e.g. the property location (town, district, street), the real estate market segment (flats, houses, plots of land, commercial premises, production buildings, garages), size, the type of market (primary, secondary) (КОКОТ 2014).

Further in the article the author determines the residential property price indices on the basis of data from 16 voivodeship capitals about the properties on offer divided into groups according to their size. The purpose of this study was to answer the question of whether flats of different sizes exhibit different price dynamics. This take on the issue does not rule out the possibility of examining price dynamics within other sub-segments, such as property standard, age or location. Such a study, however, extends beyond the framework of this paper and can be the topic of a separate examination.

\section{Empirical material and research methods}

The study included observations of sets of offer prices for flats published on the otodom.pl website in 16 voivodeship capitals. The observations were conducted on a regular basis, on the last day of each month from May to December 2013. The quantities of the offer prices are shown in Table 1 (information about May is missing because at the initial stage of the study, the author failed to collect quantitative data concerning individual sets of offer prices).

The data were divided into groups by their floor area:

1) all flats,

2) flats up to $40 \mathrm{~m}^{2}$,

3) flats from 40 to $60 \mathrm{~m}^{2}$,

4) flats larger than $60 \mathrm{~m}^{2}$

Table 1

Number of offers in individual cities

\begin{tabular}{|l|r|r|r|r|r|r|r|}
\hline \multicolumn{1}{|c|}{ City } & \multicolumn{1}{c|}{6.2013} & \multicolumn{1}{c|}{7.2013} & \multicolumn{1}{c|}{8.2013} & 9.2013 & 10.2013 & 11.2013 & 12.2013 \\
\hline Bialystok & 6,588 & 6,512 & 6,590 & 6,122 & 6,095 & 6,222 & 6,044 \\
\hline Gdansk & 13,945 & 13,778 & 13,328 & 13,783 & 13,614 & 12,904 & 12,121 \\
\hline Katowice & 5,093 & 4,751 & 4,608 & 4,816 & 4,795 & 4,548 & 4,374 \\
\hline Kielce & 1,932 & 1,885 & 2,024 & 2,052 & 1,839 & 1,743 & 2,027 \\
\hline Cracow & 27,090 & 28,512 & 26,452 & 25,223 & 27,042 & 24,602 & 23,930 \\
\hline Lublin & 5,258 & 5,351 & 5,376 & 5,151 & 4,908 & 4,764 & 4,881 \\
\hline Lodz & 9,700 & 9,594 & 9,239 & 8,731 & 8,462 & 8,384 & 8,144 \\
\hline Olsztyn & 2,912 & 2,911 & 2,511 & 2,708 & 2,883 & 2,510 & 2,186 \\
\hline Opole & 2,193 & 2,070 & 2,553 & 2,330 & 2,441 & 2,412 & 2,353 \\
\hline Poznan & 11,147 & 10,702 & 10,121 & 9,208 & 9,255 & 9,098 & 9,139 \\
\hline Rzeszow & 2,183 & 2,036 & 2,115 & 1,876 & 2,062 & 2,013 & 2,039 \\
\hline Szczecin & 10,551 & 10,548 & 9,730 & 10,008 & 9,834 & 9,255 & 8,697 \\
\hline Torun & 6,943 & 7,787 & 7,797 & 7,817 & 7,848 & 7,777 & 7,989 \\
\hline Warsaw & 78,366 & 75,301 & 69,501 & 71,513 & 69,968 & 71,893 & 70,008 \\
\hline Wroclaw & 23,133 & 21,349 & 21,305 & 21,679 & 21,930 & 22,076 & 20,455 \\
\hline Zielona Gora & 2,071 & 2,038 & 2,018 & 2,029 & 2,082 & 2,125 & 2,136 \\
\hline
\end{tabular}

Source: Own study.

Although such a classification was determined by the website browsing criteria, in the author's opinion, it represents the flat size sub-segments on the local real estate markets accurately.

On the basis of thereby collected data, for each size group in each of the 16 voivodeship capitals the author determined:

1) chain indices for property prices calculated according to the formula: 
where:

$$
I_{t}=\frac{M_{t}}{M_{t-1}}
$$

$\mathrm{M}_{\mathrm{t}}$ - the median of unitary offer prices in the period for which the index is being determined, $\mathrm{M}_{\mathrm{t}-1}$ - the median of unitary offer prices in the period preceding the period for which the index is being determined.

2) property price fixed base indices calculated according to the formula:

$$
I_{t}=\frac{M_{t}}{M_{T}}
$$

where:

$\mathrm{M}_{\mathrm{t}}$ - the median of unitary offer prices in the period for which the index is being determined,

$\mathrm{M}_{\mathrm{T}}$ - the median of unitary offer prices in the base period, i.e. May 2013.

The indices can be expressed as percentages by reducing their value by 1 and then multiplying the difference by $100 \%$.

The results have been presented in a form of diagrams. The diagrams of the chain indices show the differences in the price dynamics of flats of different sizes from month to month. If the lines representing the price index values in individual size groups oscillate in a given month, it means that the prices of flats in those size groups were subject to identical changes in the previous month. The diagrams of the fixed base indices illustrate how the differences overlap in the individual months, thus showing the differences in the price changes after seven months of the study. If, for example, after a specific period of time the lines representing the values of indices oscillate, it means that after that period of time, the prices of flats in the corresponding size groups changed in the same way.

Next, the author calculated the differences between the maximum and minimum values of monthly chain indices of changes in offer prices determined for individual size groups in each city. The category of "all flats" was not taken into consideration. The findings have been presented in Table 2. The values of differences between the indices that exceeded $1 \%$ are in bold because the author regards such contrast as rather striking for a local market. The differences among the fixed base indices were calculated in the same way, but have been presented in the form of a bar chart including only the figures for December 2013.

\section{Results and discussion}

Diagrams 1-16 show monthly chain indices of changes in the prices of flats of different sizes observed in Polish voivodeship capitals. Even a cursory analysis confirms that the prices of flats of different sizes fluctuated in different ways. The trends varied geographically. In some cities (Cracow, Lodz, Olsztyn and Warsaw) the prices wavered in all size groups according to a similar pattern, but in the majority of the cities, especially in Katowice, Kielce, Lublin, Bialystok and Zielona Gora, the segments under study appeared to "live their own lives". It was often observed that while the prices of flats up to $40 \mathrm{~m}^{2}$ were rising, larger flats were becoming cheaper (e.g. in September in Katowice, from September to November in Bialystok, from September to October in Kielce, in November in Zielona Gora, or from June to July in Torun). What is more, although the prices of small and big flats fluctuated, the rates of these changes varied greatly (e.g. in August in Katowice, in August and November in Lublin, or in September and December in Wroclaw). Table 2 shows the differences between the maximum and minimum values of the monthly chain indices of prices of flats of different sizes in the individual cities. We can see that in some cities (Bialystok and Zielona Gora) the differences were large (more than $1 \%$ of the index value expressed as a percentage), sometimes reaching as much as 3\% (Katowice and Kielce in September; Lublin in November), which should be considered a striking value regarding the fact that indices were calculated on the monthly basis.

Diagrams 17-32 present fixed base indices which demonstrate the differences in the prices of flats of different sizes, which can result from their varying dynamics. It was observed that, even in the span of many months, the prices of flats were found to fall in one size category and grow in another. This was particularly evident in Bialystok, Katowice, Kielce, Lublin and Szczecin, where the prices of small flats went up while big flats got cheaper. On the other hand, the exact opposite trend was observed in Torun and Zielona Gora, where large flats went up in price and small ones fell. Diagram 33 shows just 
how great these differences were, reaching $8 \%$ in Katowice, exceeding $5 \%$ in Torun, and ranging from 3-5\% in Szczecin, Kielce, Zielona Gora, Bialystok and Lublin. In half of the observed cities the differences remained at the level of 1-2\%. An interesting situation took place in Opole where the evident gaps in the rate of changes in the prices of flats of different size eventually leveled off at the end of the year.
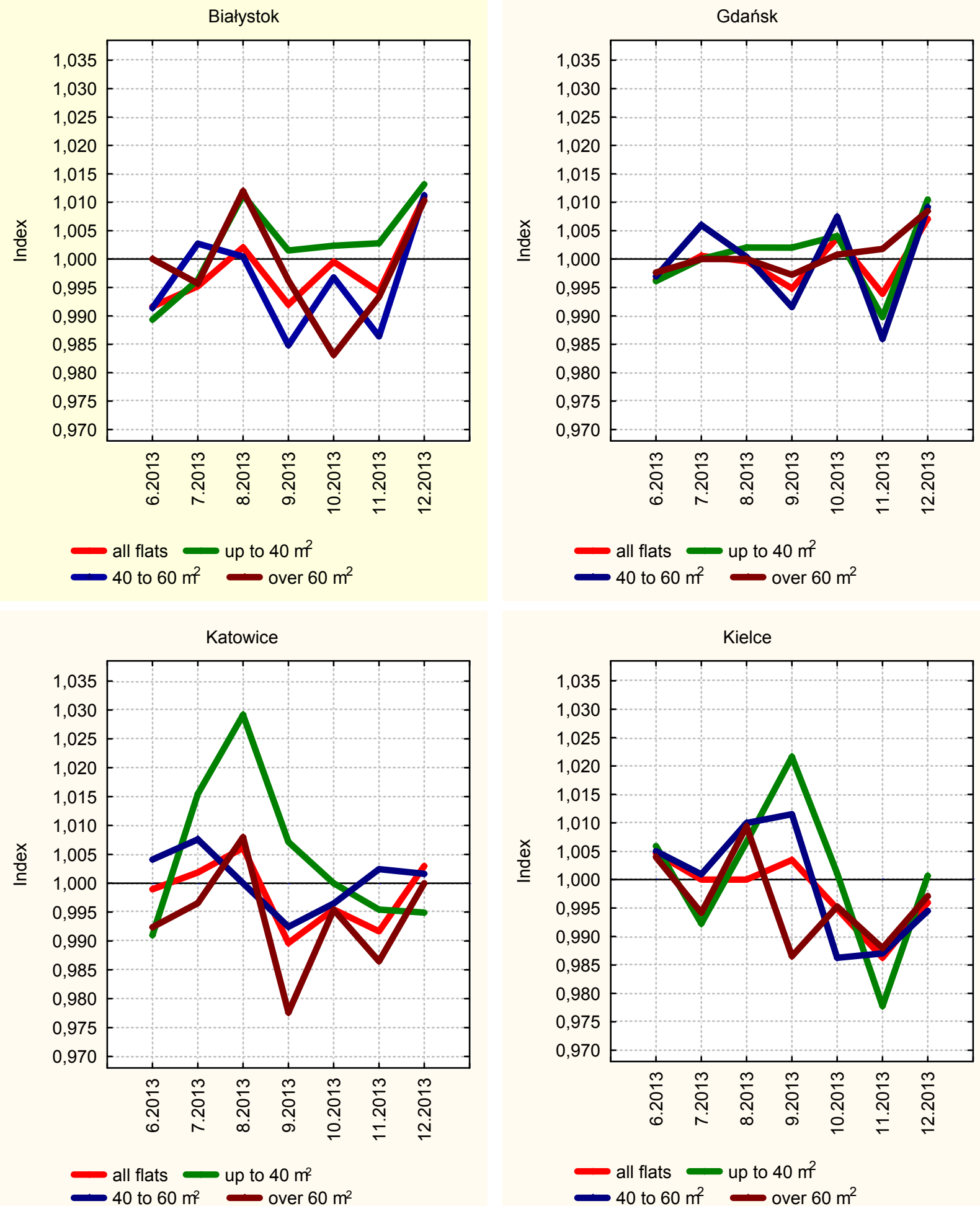

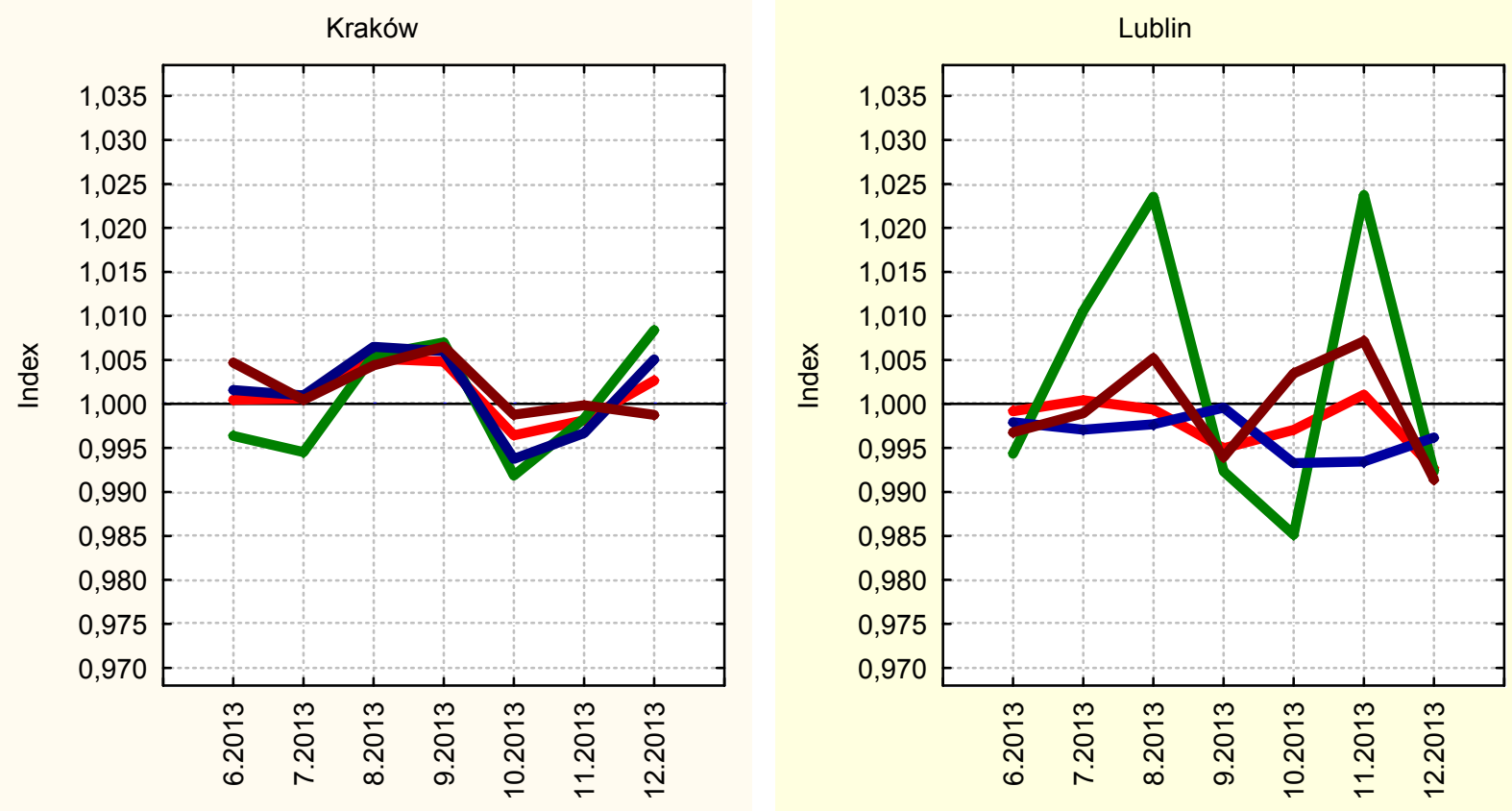

all flats $\longrightarrow$ up to $40 \mathrm{~m}^{2}$

- 40 to $60 \mathrm{~m}^{2} \longrightarrow$ over $60 \mathrm{~m}^{2}$

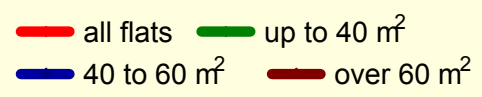
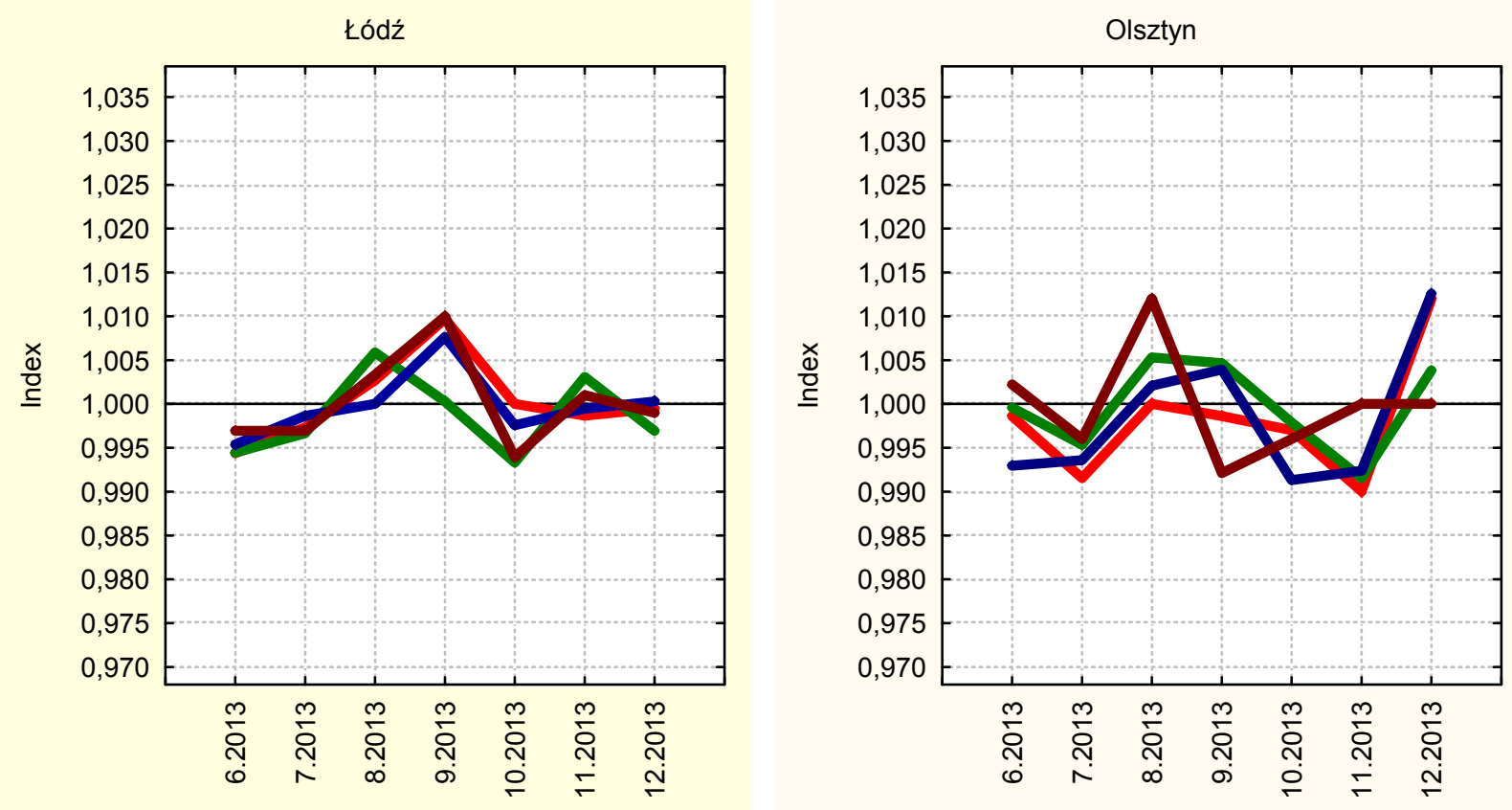

all flats $\longrightarrow$ up to $40 \mathrm{~m}^{2}$
40 to $60 \mathrm{~m}^{2} \stackrel{\text { over }}{ } 60 \mathrm{~m}^{2}$

all flats $\longrightarrow$ up to $40 \mathrm{~m}^{2}$
40 to $60 \mathrm{~m}^{2} \longrightarrow$ over $60 \mathrm{~m}^{2}$ 

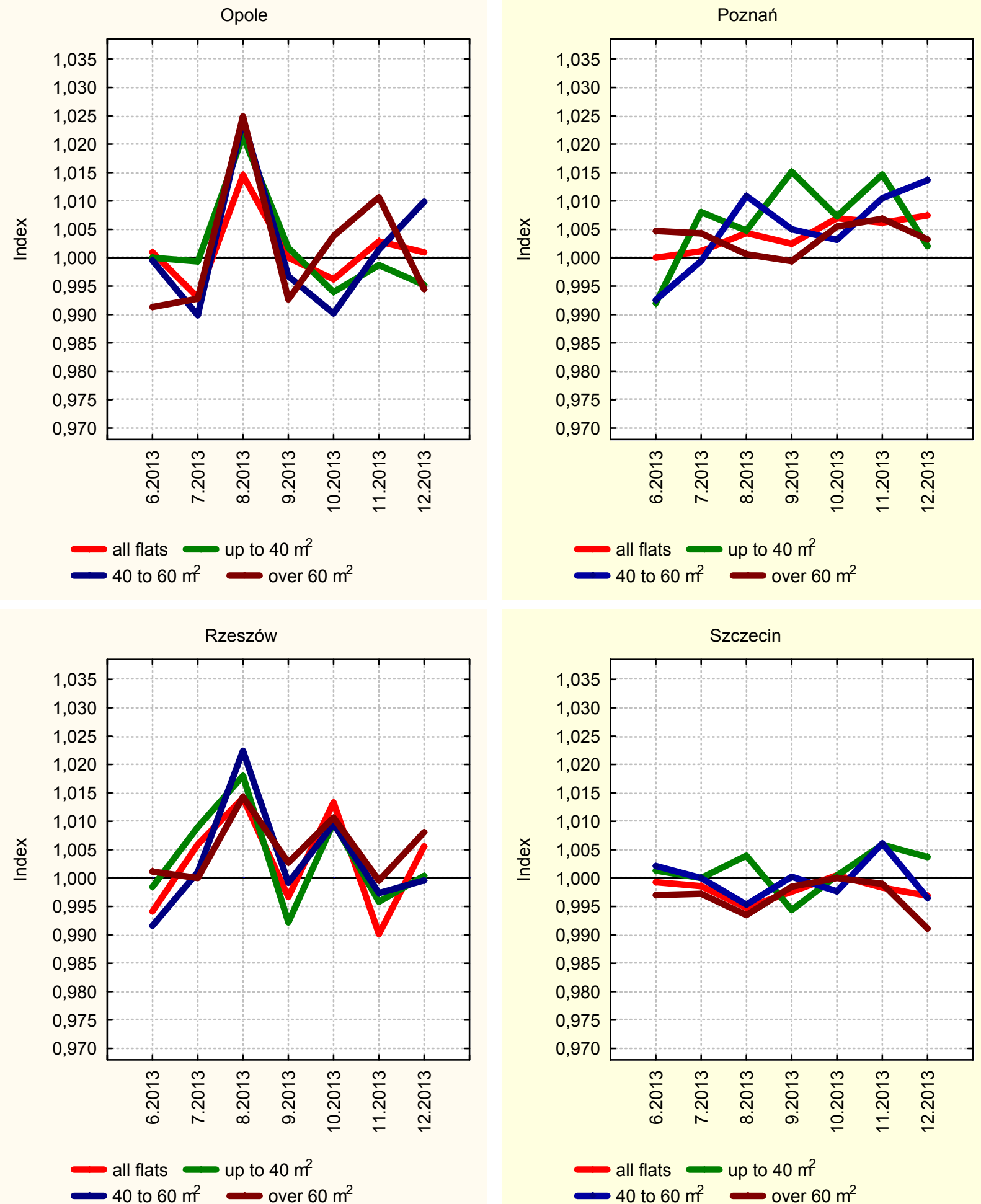

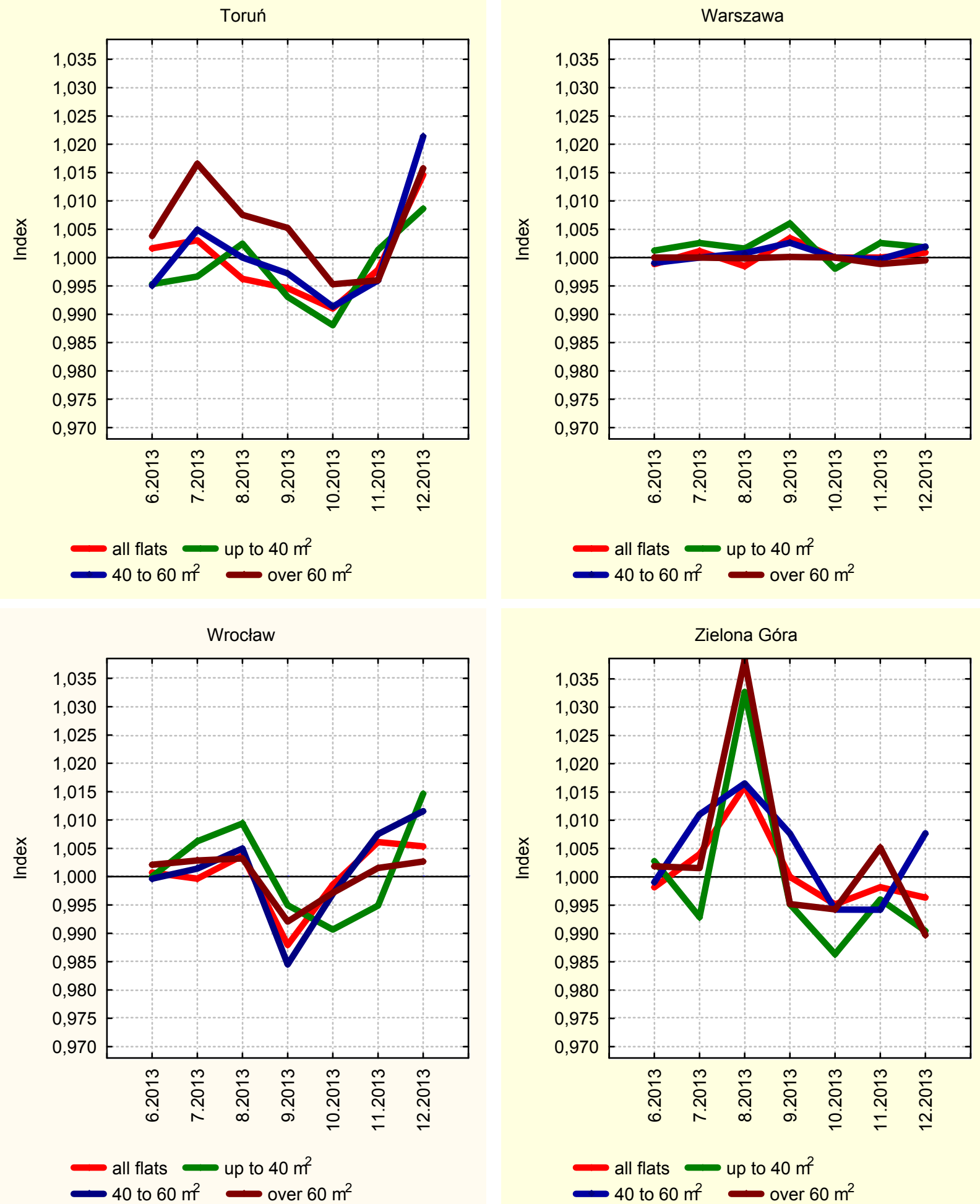

Diagrams 1-16. Monthly chain indices of changes in flat prices in individual cities by flat size. Source: own study. 

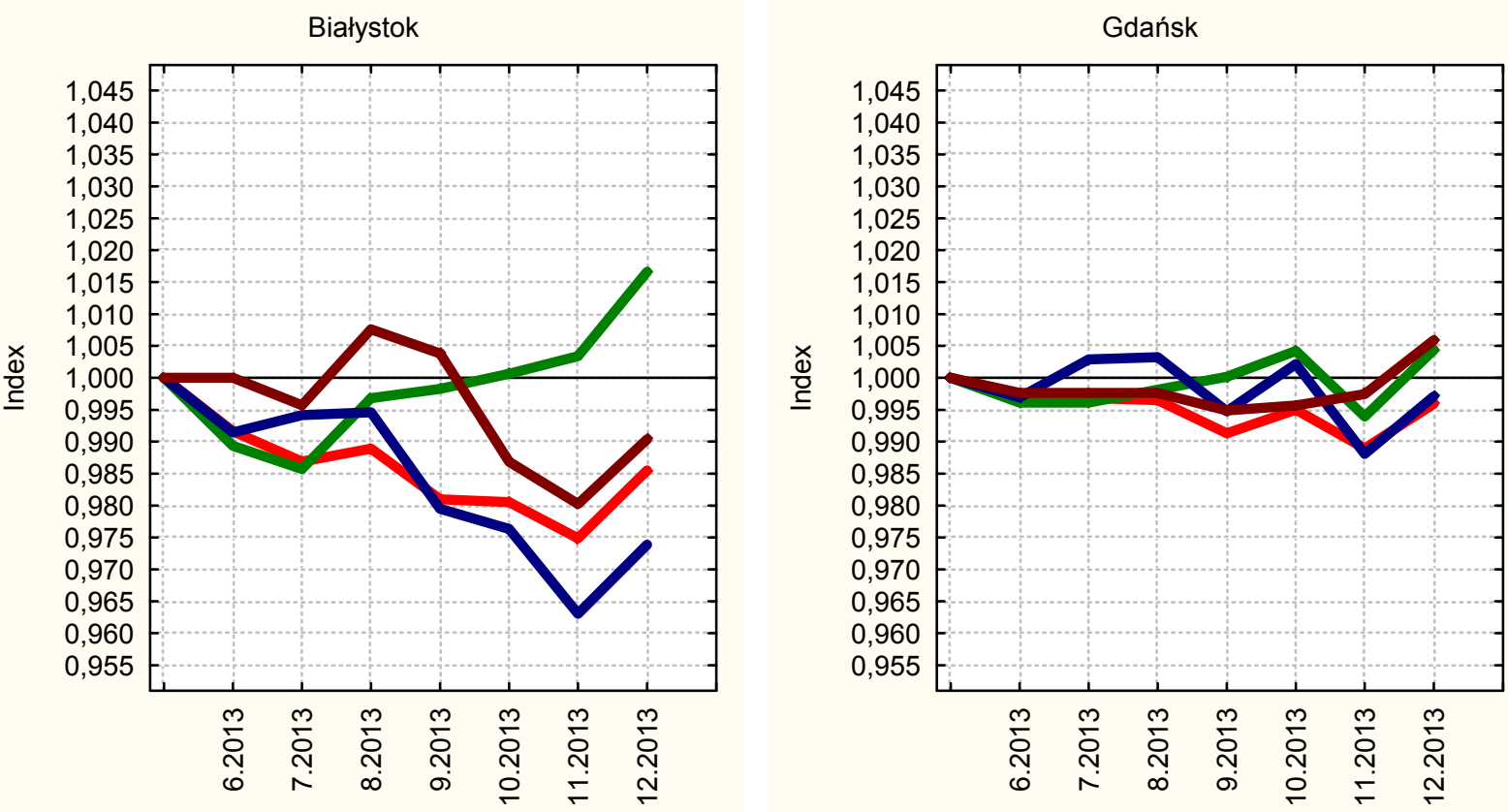

all flats up to $40 \mathrm{~m}^{2}$

40 to $60 \mathrm{~m}^{2} \longrightarrow$ over $60 \mathrm{~m}^{2}$

all flats $\longrightarrow$ up to $40 \mathrm{~m}^{2}$

$\longrightarrow 40$ to $60 \mathrm{~m}^{2} \rightleftharpoons$ over $60 \mathrm{~m}^{2}$

Katowice

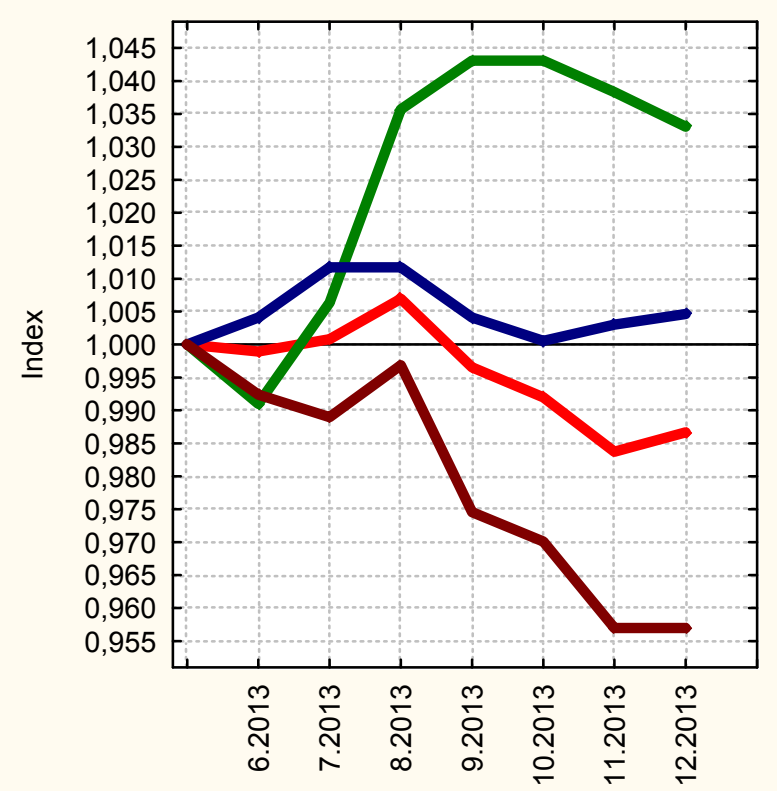

all flats up to $40 \mathrm{~m}^{2}$

$\longrightarrow$ to $60 \mathrm{~m}^{2} \longrightarrow$ over $60 \mathrm{~m}^{2}$
Kielce

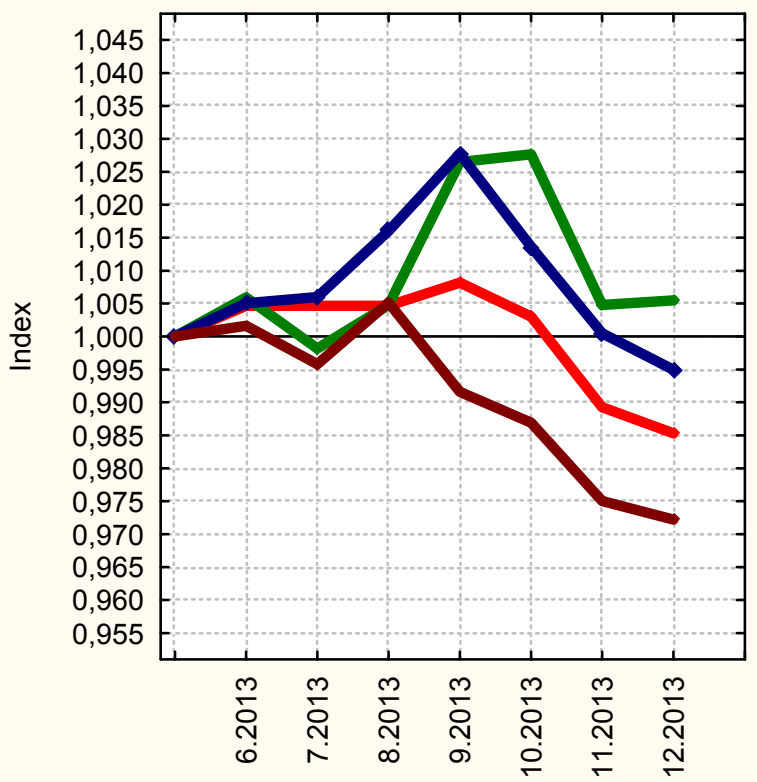

all flats $\longrightarrow$ up to $40 \mathrm{~m}^{2}$

$\longrightarrow 0$ to $60 \mathrm{~m}^{2} \longrightarrow$ over $60 \mathrm{~m}^{2}$ 

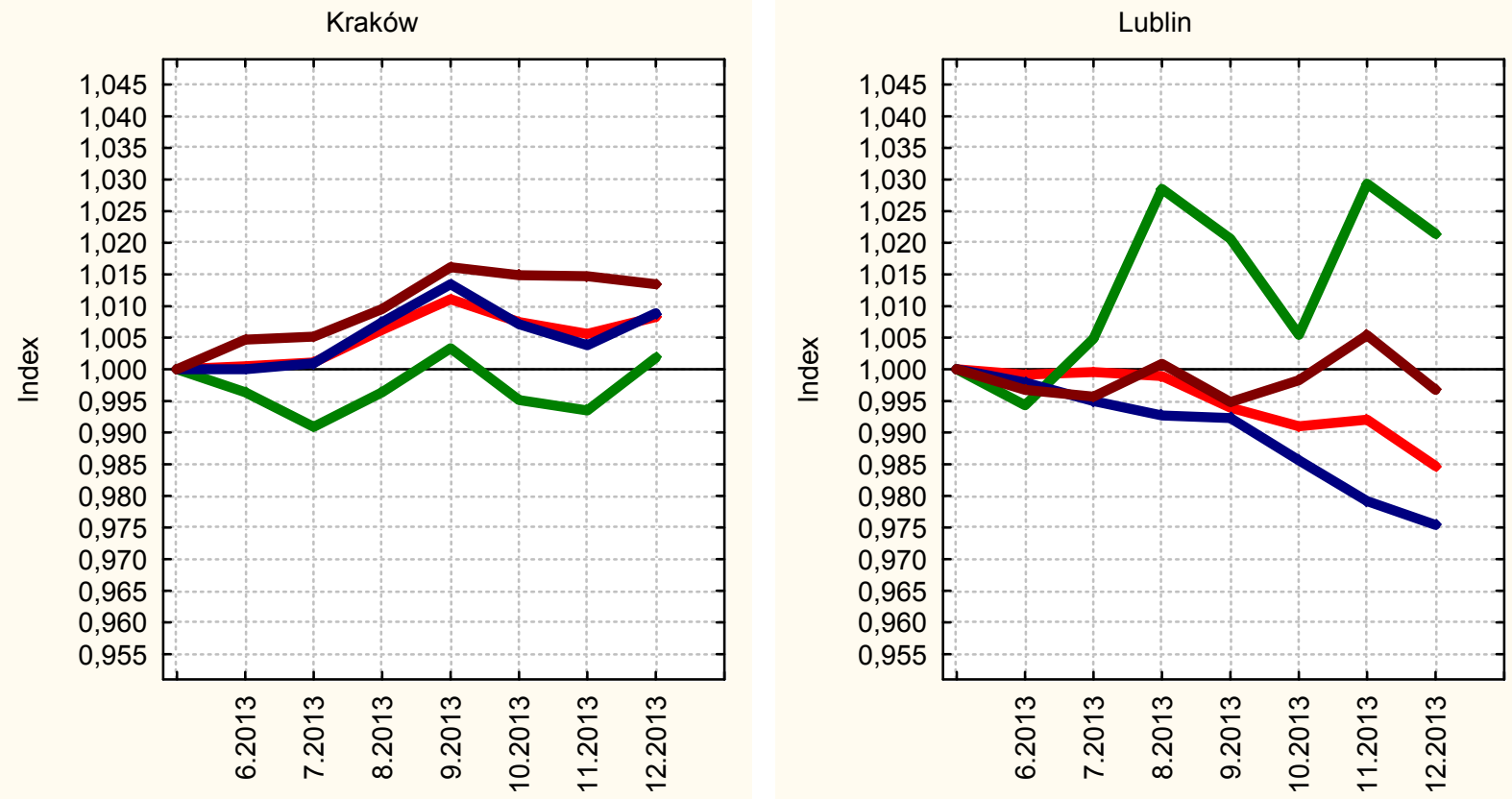

all flats $\longrightarrow$ up to $40 \mathrm{~m}^{2}$

$\longrightarrow 0$ to $60 \mathrm{~m}^{2} \longrightarrow$ over $60 \mathrm{~m}^{2}$

$$
\begin{aligned}
& \text { all flats } \underset{\text { up to }}{\longrightarrow} 40 \mathrm{~m}^{2} \\
& 40 \text { to } 60 \mathrm{~m}^{2} \quad \text { over } 60 \mathrm{~m}^{2}
\end{aligned}
$$
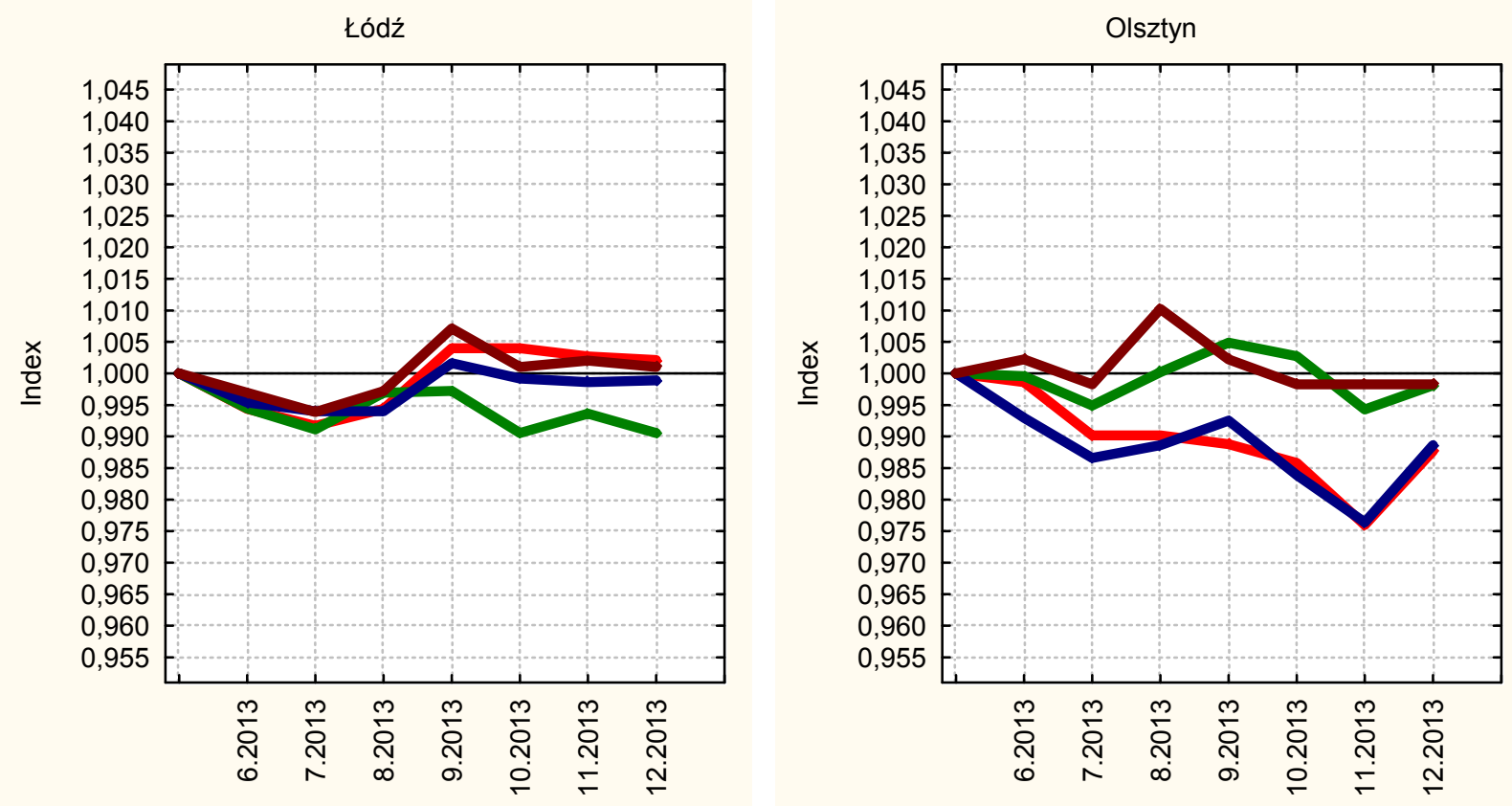

all flats $\rightleftharpoons$ up to $40 \mathrm{~m}^{2}$
40 to $60 \mathrm{~m}^{2} \longrightarrow$ over $60 \mathrm{~m}^{2}$

all flats $\rightleftharpoons$ up to $40 \mathrm{~m}^{2}$
40 to $60 \mathrm{~m}^{2} \stackrel{\text { over }}{2} 60 \mathrm{~m}^{2}$ 

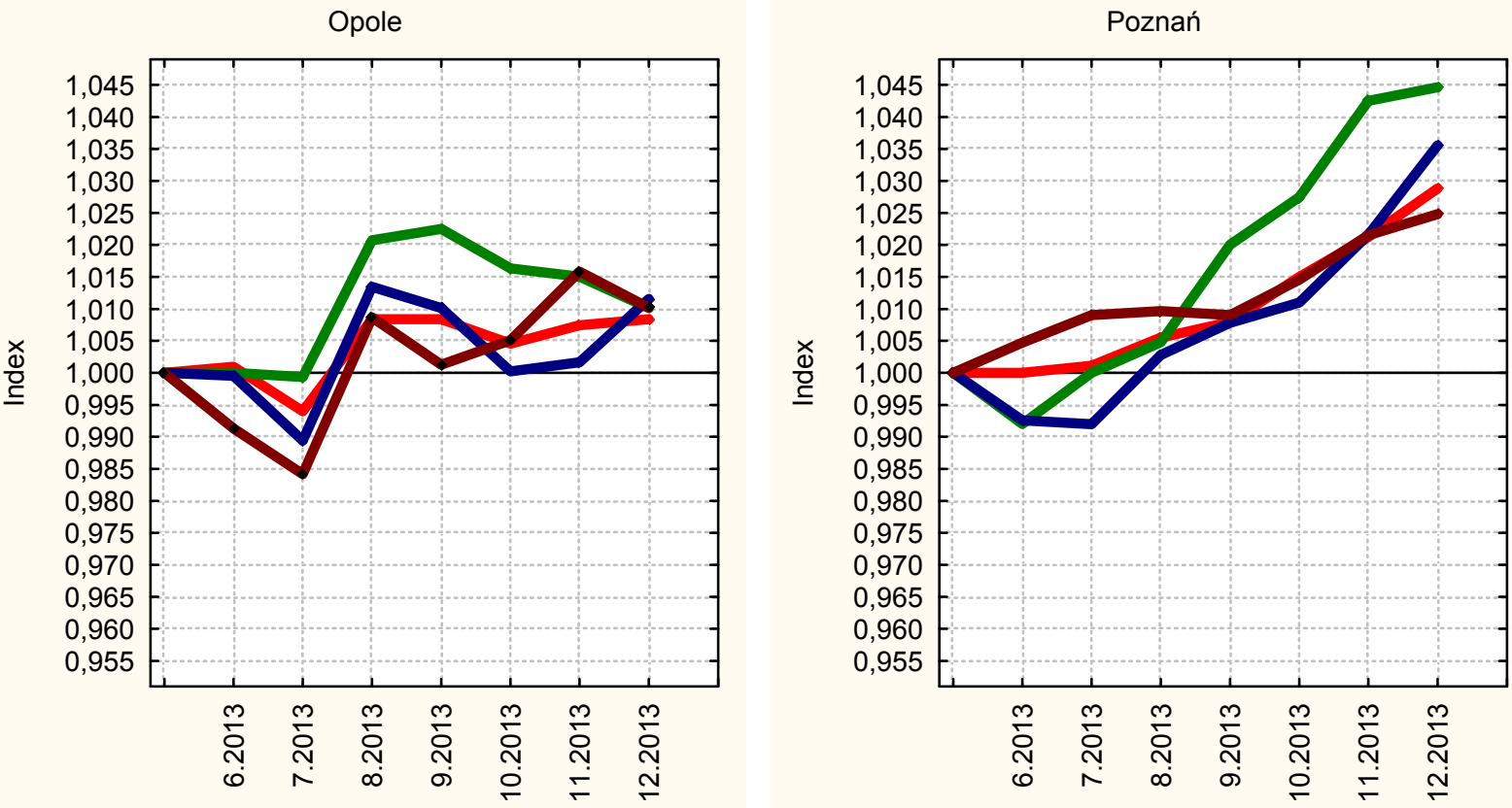

all flats up to $40 \mathrm{~m}^{2}$

$\longrightarrow 40$ to $60 \mathrm{~m}^{2} \longrightarrow$ over $60 \mathrm{~m}^{2}$

all flats $\longrightarrow$ up to $40 \mathrm{~m}^{2}$

$\longrightarrow 40$ to $60 \mathrm{~m}^{2} \rightleftharpoons$ over $60 \mathrm{~m}^{2}$
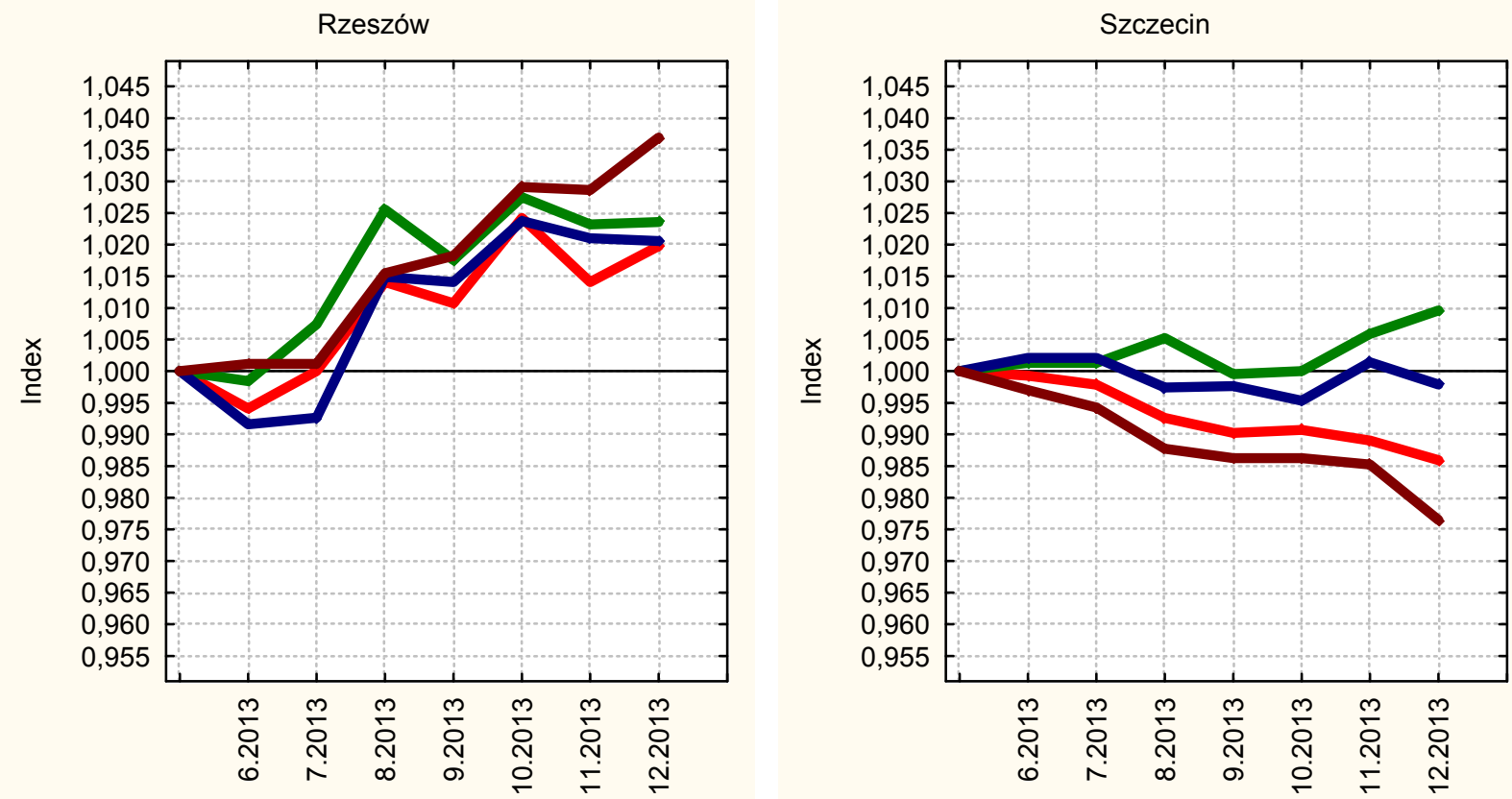

all flats $\longrightarrow$ up to $40 \mathrm{~m}^{2}$

$\longrightarrow 0$ to $60 \mathrm{~m}^{2} \longrightarrow$ over $60 \mathrm{~m}^{2}$

all flats $\longrightarrow$ up to $40 \mathrm{~m}^{2}$

$\longrightarrow 0$ to $60 \mathrm{~m}^{2} \longrightarrow$ over $60 \mathrm{~m}^{2}$ 

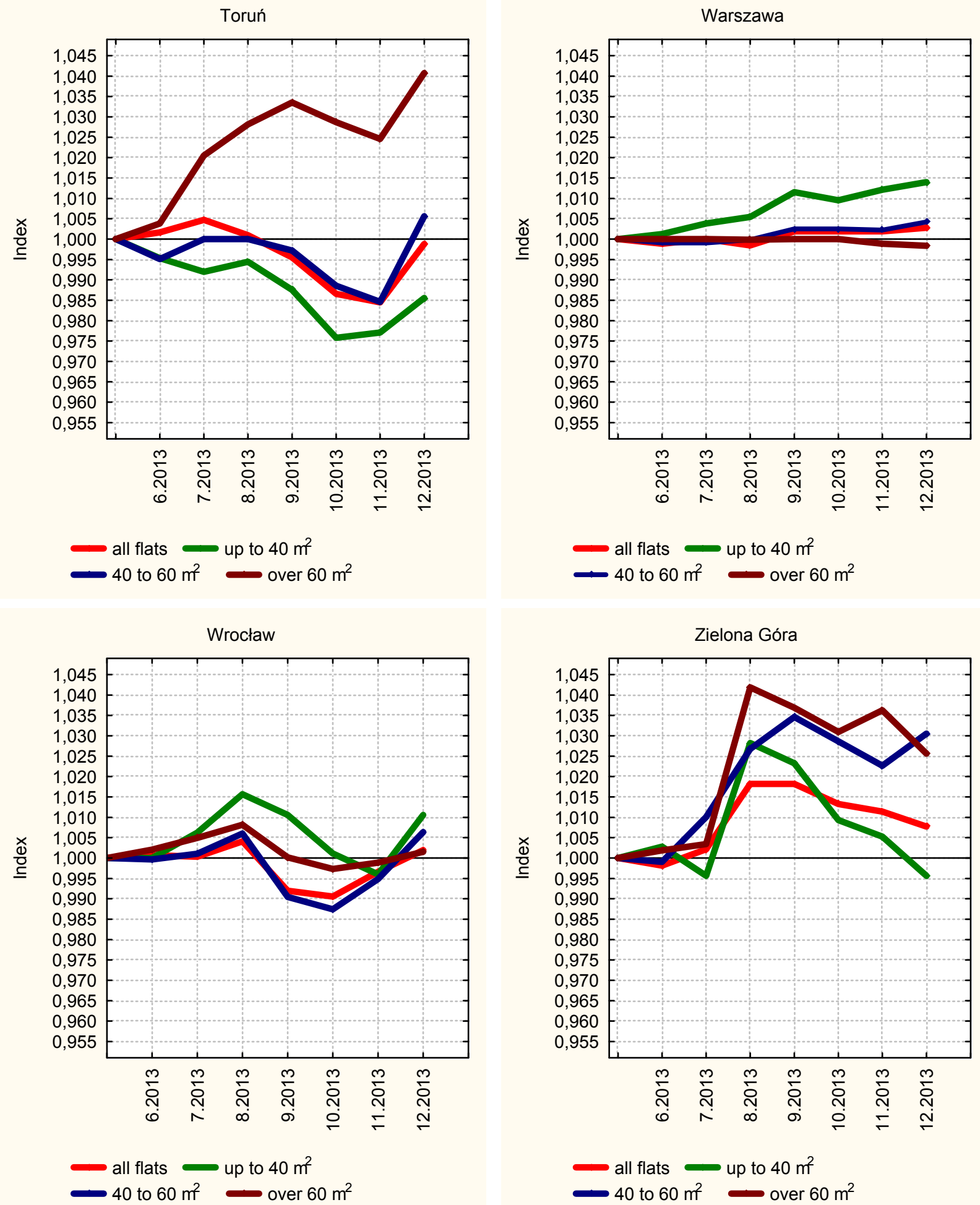

Diagrams 17-32. Monthly fixed base indices of changes in flat prices in individual cities by flat size. Source: own study. 
Table 2

Differences between minimum and maximum values of monthly chain indices of offer prices determined for individual flat size categories in individual cities.

\begin{tabular}{|l|r|r|r|r|r|r|r|}
\hline \multicolumn{1}{|c|}{ City } & \multicolumn{1}{c|}{6.2013} & \multicolumn{1}{c|}{7.2013} & \multicolumn{1}{c|}{8.2013} & 9.2013 & 10.2013 & 11.2013 & 12.2013 \\
\hline Białystok & $\mathbf{0 . 0 1 0 7}$ & 0.0070 & $\mathbf{0 . 0 1 1 5}$ & $\mathbf{0 . 0 1 6 7}$ & $\mathbf{0 . 0 1 9 2}$ & $\mathbf{0 . 0 1 6 4}$ & 0.0028 \\
\hline Gdańsk & 0.0015 & 0.0060 & 0.0020 & $\mathbf{0 . 0 1 0 5}$ & 0.0066 & $\mathbf{0 . 0 1 5 8}$ & 0.0020 \\
\hline Katowice & $\mathbf{0 . 0 1 3 1}$ & $\mathbf{0 . 0 1 8 9}$ & $\mathbf{0 . 0 2 9 1}$ & $\mathbf{0 . 0 2 9 5}$ & 0.0046 & $\mathbf{0 . 0 1 6 0}$ & 0.0067 \\
\hline Kielce & 0.0020 & 0.0087 & 0.0033 & $\mathbf{0 . 0 3 5 1}$ & $\mathbf{0 . 0 1 4 8}$ & $\mathbf{0 . 0 1 0 2}$ & 0.0062 \\
\hline Cracow & 0.0083 & 0.0064 & 0.0021 & 0.0010 & 0.0069 & 0.0031 & 0.0096 \\
\hline Lublin & 0.0036 & $\mathbf{0 . 0 1 3 5}$ & $\mathbf{0 . 0 2 5 8}$ & 0.0072 & $\mathbf{0 . 0 1 8 3}$ & $\mathbf{0 . 0 3 0 3}$ & 0.0047 \\
\hline Eódź & 0.0025 & 0.0020 & 0.0059 & 0.0097 & 0.0042 & 0.0036 & 0.0033 \\
\hline Olsztyn & 0.0093 & 0.0024 & 0.0099 & $\mathbf{0 . 0 1 2 6}$ & 0.0066 & 0.0084 & $\mathbf{0 . 0 1 2 6}$ \\
\hline Opole & 0.0087 & 0.0095 & 0.0035 & 0.0091 & $\mathbf{0 . 0 1 3 6}$ & $\mathbf{0 . 0 1 2 0}$ & $\mathbf{0 . 0 1 5 4}$ \\
\hline Poznań & $\mathbf{0 . 0 1 2 7}$ & 0.0086 & $\mathbf{0 . 0 1 0 3}$ & $\mathbf{0 . 0 1 5 8}$ & 0.0042 & 0.0078 & $\mathbf{0 . 0 1 1 6}$ \\
\hline Rzeszów & 0.0096 & 0.0090 & 0.0081 & $\mathbf{0 . 0 1 0 5}$ & 0.0011 & 0.0037 & 0.0085 \\
\hline Szczecin & 0.0051 & 0.0028 & $\mathbf{0 . 0 1 0 5}$ & 0.0059 & 0.0028 & 0.0071 & $\mathbf{0 . 0 1 2 6}$ \\
\hline Toruń & 0.0087 & $\mathbf{0 . 0 1 9 9}$ & 0.0075 & $\mathbf{0 . 0 1 2 2}$ & 0.0072 & 0.0054 & $\mathbf{0 . 0 1 2 7}$ \\
\hline Warsaw & 0.0022 & 0.0026 & 0.0017 & 0.0059 & 0.0020 & 0.0037 & 0.0025 \\
\hline Wrocław & 0.0024 & 0.0048 & 0.0062 & $\mathbf{0 . 0 1 0 4}$ & 0.0065 & $\mathbf{0 . 0 1 2 6}$ & $\mathbf{0 . 0 1 2 0}$ \\
\hline Zielona Góra & 0.0037 & $\mathbf{0 . 0 1 8 1}$ & $\mathbf{0 . 0 2 1 8}$ & $\mathbf{0 . 0 1 2 5}$ & 0.0079 & $\mathbf{0 . 0 1 1 0}$ & $\mathbf{0 . 0 1 8 0}$ \\
\hline
\end{tabular}

Source: Own study.

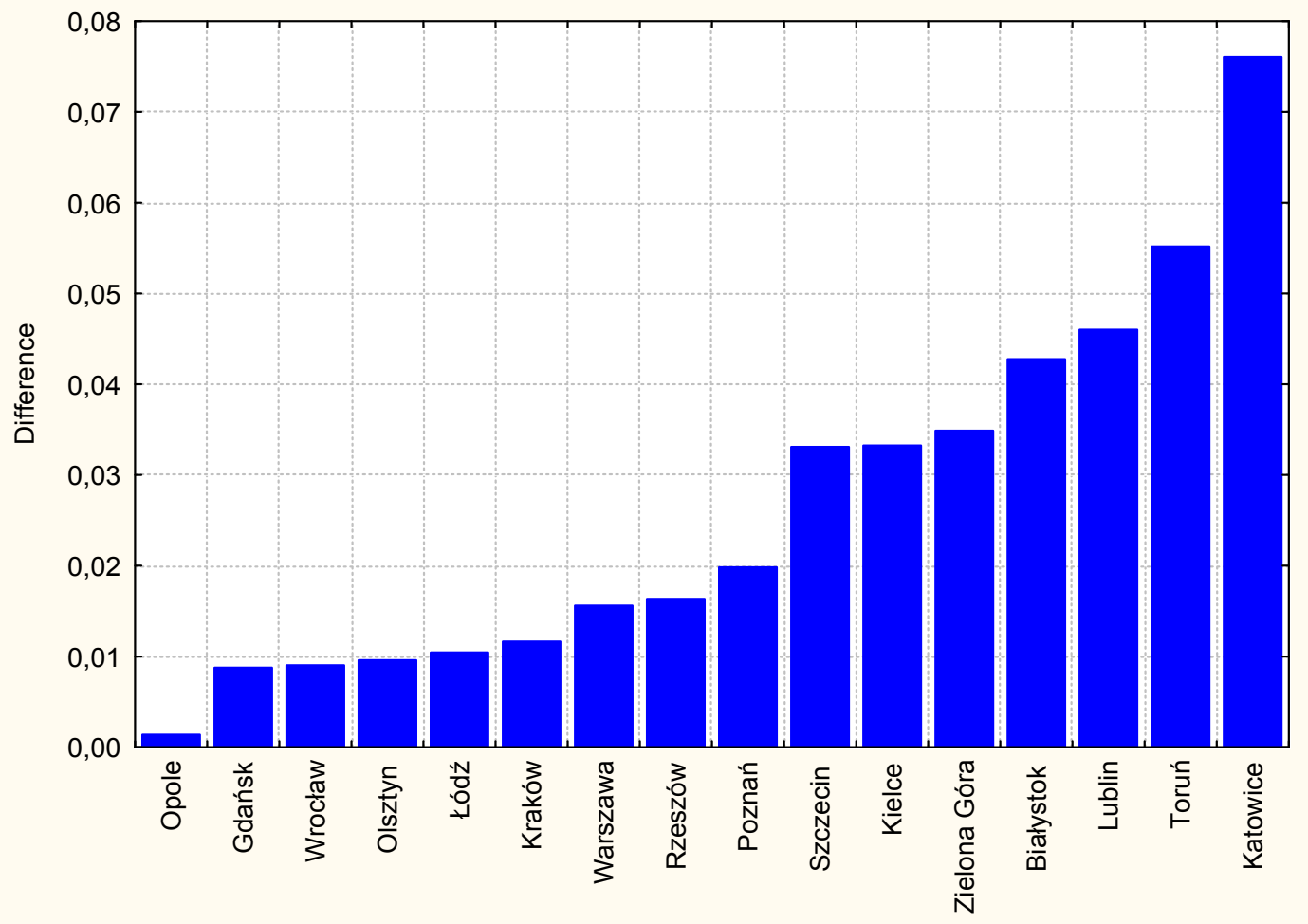

Diagram 33. Differences between minimum and maximum values of monthly fixed base indices of offer prices determined for individual flat size categories in individual cities (May 2013 $=1$ ) as of December 2013. Source: own study.

The above presented study confirms that the same local real estate markets can experience price fluctuations that vary significantly between the different sub-segments of flat size. Therefore, it seems legitimate to recommend the segmentation of the residential property market by the size of flats 
offered on the market so that real property price indices can be determined more accurately. The author does not rule out the option of examining the real property price dynamics in sub-segments determined according to other criteria, such as property standard, age or location. Such an alternative, however, requires further more in-depth studies. Keeping in mind the fact that this study covered a relatively short period of time, the above presented findings should be considered preliminary, with the author intending to continue his research in the nearest future.

\section{References}

BOKHARI S., GELTNER D. 2010. Estimating Real Estate Price Movements for High Frequency Tradable Indexes in a Scarce Data Environment. The Journal of Real Estate Finance and Economics. Vol. 45, Issue 2.

Clapp J.M., GiacotTo C.: Estimating Price Indices for Residential Property: A Comparison of Repeat Sales and Assessed Value Methods. Journal of the American Statistical Association. Vol. 87.

DitTMAnN I. 2013. Primary and secondary residential real estate markets in poland - analogies in offer and transaction price development, Real Estate Management and Valuation. Volume 21, Issue 1, Pages 3948, ISSN (Online) 1733-2478, DOI: 10.2478/remav-2013-0006.

FORYŚ I., KOKOT S. 2001. Problemy badania rynku nieruchomości. Zeszyty Naukowe U.S. No. 318, "Mikroekonometria w teorii i praktyce”, Prace Katedry Ekonometrii i Statystyki, Szczecin.

FRANCKE M.K. 2010. Repeat Sales Index for Thin Markets. The Journal of Real Estate Finance and Economics. Vol. 41, Issue 1.

GŁOWACKI Z., PRZEWŁOCKI S. 1997. Monitoring lokalnego rynku nieruchomości na przykładzie ofert prasowych i transakcji notarialnych. Wycena No. 2(37), Olsztyn.

GUO X., ZHENG S., GELTNER D., LIU H. 2014. A new approach for constructing home price indices: The pseudo repeat sales model and its application in China. Journal of Housing Economics. Vol. 25.

КОКОт S. 2014. W poszukiwaniu indeksów cen nieruchomości, Studia i Prace Wydziału Nauk Ekonomicznych i Zarządzania Uniwersytetu Szczecińskiego "Metody ilościowe w ekonomii” Wydawnictwo Uniwersytetu Szczecińskiego, Szczecin 2014 (w druku, po recenzji).

KокОT S., BAS M. 2013. Evaluation of the Applicability of Statistical Methods in Studies on Price Dynamics on the Real Estate Market, Real Estate Management and Valuation. Volume 21, Issue 1, Pages 49-58, ISSN (Online) 1733-2478, DOI: 10.2478/remav-2013-0007.

KośKA T. 1996. Łódzki rynek nieruchomości, ZNPŁ. Budownictwo z. no. 45. Łódź.

КОКОТ S. 2000. Wykorzystanie ogłoszeń prasowych do analiz rynku nieruchomości, Zeszyty Naukowe U.S. Nr 269, „Metody ilościowe w ekonomii”, Szczecin.

Nicholas T., Scherbina A. 2013. Real Estate Prices During the Roaring Twenties and the Great Depression. Real Estate Economics. Vol. 41, Issue 2.

Rozporządzenie Rady Ministrów z dnia 21 września 2004 r. w sprawie wyceny nieruchomości i sporządzania operatu szacunkowego.

TrojAneK R. 2008. Wahania cen na rynku mieszkaniowym. Wyd. Akademii Ekonomicznej w Poznaniu, Poznań.

TrojAnEK R. 2009. Porównanie metody średniej oraz średniej ważonej do konstruowania indeksów cen nieruchomości mieszkaniowych. Studia i Materiały Towarzystwa Naukowego Nieruchomości. Vol 17, no. 2.

TrojaneK R. 2010. Porównanie metod prostych oraz regresji hedonicznej do konstruowania indeksów cen mieszkań. Studia i Materiały Towarzystwa Naukowego Nieruchomości. Vol 18, no. 1.

WoOD R. 2005. A Comparison of UK Residential Mouse Price Indices. BIS Paper, no. 21. 